\title{
Analisis Sektor Ekonomi Serta Pengaruh Investasi terhadap Sektor Basis Dan Non Basis 2 Kabupaten di Provinsi Jawa Tengah
}

\author{
Margaretha Dwi Suprapti Setyaningrum, Niniek Imaningsih, Riko Setya Wijaya \\ Fakultas Ekonomi dan Bisnis Universitas Pembangunan Nasional "Veteran" Jawa Timur \\ Correspondence email: 17011010100@student.upnjatim.ac.id
}

\begin{abstract}
Abstrak. Tujuan penelitian ini untuk mengetahui adanya sektor basis dan non basis, pertumbuhan sektor ekonomi, tipe daerah jika dilihat dari pertumbuhan ekonomi, serta bagaimana pengaruh investasi terhadap sektor basis dan non basis di Kabupaten Cilacap dan Kabupaten Sukoharjo di Provinsi Jawa Tengah. Penelitian ini menggunakan data time series dengan kurun tahun selama 4 tahun yaitu periode 2016-2019. Teknik analisis yang digunakan adalah analisis LQ (Location Quetient), Shift-Share, Tipologi Klassen, analisis regresi linier sederhana dengan menggunakan spss 13.0. Berdasarkan hasil analisis LQ disimpulkan bahwa Kabupaten Sukoharjo merupakan kabupaten yang lebih unggul dari pada Kabupaten Cilacap apabila dilihat dari jumlah sektor unggulannya. Pertumbuhan sektor ekonomi kedua kabupaten mengalami kenaikan dan penurunan di setiap tahunnya. Berdasarkan hasil analisis regresi menunjukkan bahwa secara simultan investasi berpengaruh secara signifikan terhadap pertumbuhan sektor basis dan non basis di dua kabupaten. Hasil klasifikasi daerah dijelaskan bahwa Kabupaten Cilacap beradi di kuadran IV dan Kabupaten Sukoharjo berada di kuadran I.
\end{abstract}

Kata Kunci: Pertumbuhan Ekonomi Daerah, Location Quetient (LQ), Shift Share, Penanaman Modal Dalam Negeri, Tipologi Klassen

Abstract. The purpose of this study was to determine the existence of basic and non-basic sectors, economic sector growth, regional types when viewed from economic growth, as well as how investment affects the basic and non-basic sectors in Cilacap Regency and Sukoharjo Regency in Central Java Province. This study uses time series data with a period of 4 years, namely the period 2016-2019. The analysis technique used is LQ (Location Quetient) analysis, Shift-Share, Klassen typology, simple linear regression analysis using spss 13.0. Based on the results of the $L Q$ analysis, it was revealed that Sukoharjo Regency is a district that is superior to that of Cilacap Regency in terms of the number of its leading sectors. The growth of the economic sectors of the two districts has increased and decreased every year. Based on the results of the regression analysis, it shows that investment has a significant effect on the growth of the basic and non-basic sectors in the two districts. The results of the regional classification explained that Cilacap Regency was in quadrant IV and Sukoharjo Regency was in quadrant I.

Keywords: Regional Economic Growth, Location Quetient (LQ), Shift Share, Domestic Investment, Klassen typology

\section{PENDAHULUAN}

Pertumbuhan ekonomi adalah inti penting dalam proses pembangunan nasional dan wilayah di Indonesia. Target utama dalam penyusunan rencana pembangunan fisik dan sosial sampai saat ini merupakan pertumbuhan ekonomi yang cukup tinggi. Melalui pertumbuhan ekonomi wilayah yang cukup tinggi diharapkan kesejahteraan masyarakat secara bertahap akan dapat pula di tingkatkan (Sjafrizal, 2012).

Menurut Arsyad (2004, p.13) pertumbuhan ekonomi diartikan sebagai kenaikan produk domestik bruto dengan tidak memandang apakah kenaikan itu lebih besar ataupun lebih kecil dari tingkat pertumbuhan penduduk, atau apakah pertumbuhan ekonomi terjadi atau tidak. Mengingat pentingnya pertumbuhan ekonomi daerah, sehingga setiap daerah dituntut untuk mampu mengembangkan potensi dari daerah itu sehingga terciptanya keuanggualan dari sektor ekonomi yang ada di daerah dan dapat berdampak satu sama dengan sektor yang lain terhadap Produk Domestik Regional Bruto.

Jawa Tengah merupakan salah satu provinsi dibagian tengah Pulau Jawa dengan luas wilayah 34,558 $\mathrm{km}^{2}$ dan jumlah penduduk sebesar 32.380 .678 jiwa (Statistik, 2020). Meskipun merupakan provinsi yang terletak di bagian tengah pulau Jawa namun pertumbuhan ekonomi di Jawa Tengah dari tahun 2016 hingga tahun 2019 menunjukkan tren yang relative positif.

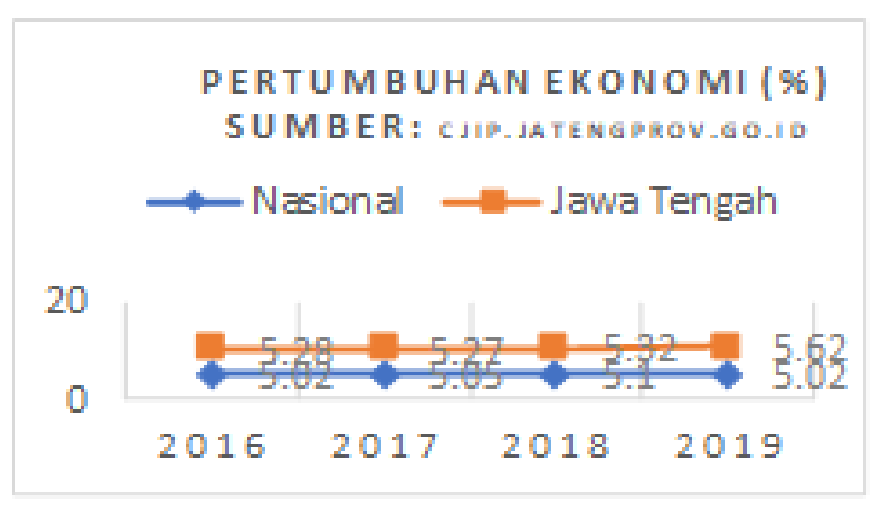

Gambar 1. Pertumbuhan Ekonomi Jawa Tengah

Menurut data pertumbuhan ekonomi di Jawa Tengah pada tahun 2019 sebesar 5,62\% lebih tinggi dari pertumbuhan ekonomi nasional sebesar 5,02\%. Di Jawa Tengah terdapat beberapa kabupaten ataupun kota besar yang memberikan sumbangan terbesar terhadap PDRB provinsi Jawa Tengah. Masing-masing kabupaten/kota di Jawa Tengah memberikan konstribusinya dalam setiap 
sektor dari tujuh belas sektor yang ada dengan kemampuan dan kapasitas yang dimiliki oleh daerah tersebut.

Dalam penelitian ini penulis memilih 2 Kabupaten di Provinsi Jawa Tengah untuk dijadikan penelitian yaitu Kabupaten Cilacap dan Kabupaten Sukoharjo sebagai objek penelitian. Dari data yang diperoleh dari Badan Pusat Statistik, perkembangan Produk Domestik Regional Bruto (PDRB) yang ada di Kabupaten Cilacap dan Kabupaten Sukoharjo dalam rata-rata peningkatan jumlah PDRB dari tahun 2016-2019 menglami kenaikan meskipun bertahap setiap tahunnya. Menurut data pertumbuhan ekonomi di Jawa Tengah pada tahun 2019 sebesar 5,62\% lebih tinggi dari pertumbuhan ekonomi nasional sebesar 5,02\%. Di Jawa Tengah terdapat beberapa kabupaten ataupun kota besar yang memberikan sumbangan terbesar terhadap PDRB provinsi Jawa Tengah. Masing-masing kabupaten/kota di Jawa Tengah memberikan konstribusinya dalam setiap sektor dari tujuh belas sektor yang ada dengan kemampuan dan kapasitas yang dimiliki oleh daerah tersebut.

Investasi juga dapat menjadi faktor pendorong dalam pertumbuhan ekonomi dengan melihat tujuan yang ada dalam UU no 25/2007 tentang penanaman modal. Investasi yang merupakan langkah awal dalam kegiatan pembangunan ekonomi dapat mempercepat pembangunan ekonomi nasional serta mewujudkan kedaulatan politik dan ekonomi di Indonesia dibutuhkan peningkatan penanaman modal untuk mengolah potensi ekonomi menjadi kekuatan ekonomi riil dengan memanfaatkan modal yang berasal dari dalam negeri maupun dari luar negeri (Purnamasari, 2015). Dalam penelitian ini digunakan istilah Penanaman modal dalam negeri, yang berarti kegiatan menanam modal untuk melakukan usaha di wilayah daerah Kabupaten Cilacap dan Kabupaten Sukoharjo.

Pada gambar 1.2 dapat dilihat perkembangan realisasi investasi dalam negeri Kabupaten Cilacap dan Kabupaten Sukoharjo dalam kurun waktu 4 tahun terakhir yakni tahun 2016-2019. Perubahan investasi Kabupaten Cilacap dan Kabupaten Sukoharjo ini dari tahun 2016 sampai tahun 2019 mengalami fluktuasi secara nominal. Perkembangan investasi penanaman modal dalam negeri (PMDN) di Kabupaten Cilacap pada tahun 2017 dengan realisasi mencapai 395 juta dengan jumlah proyek 17 ini termasuk penurunan angka investasi dari tahun sebelumnya mencapai 12 juta dengan jumlah 17 proyek tetap.

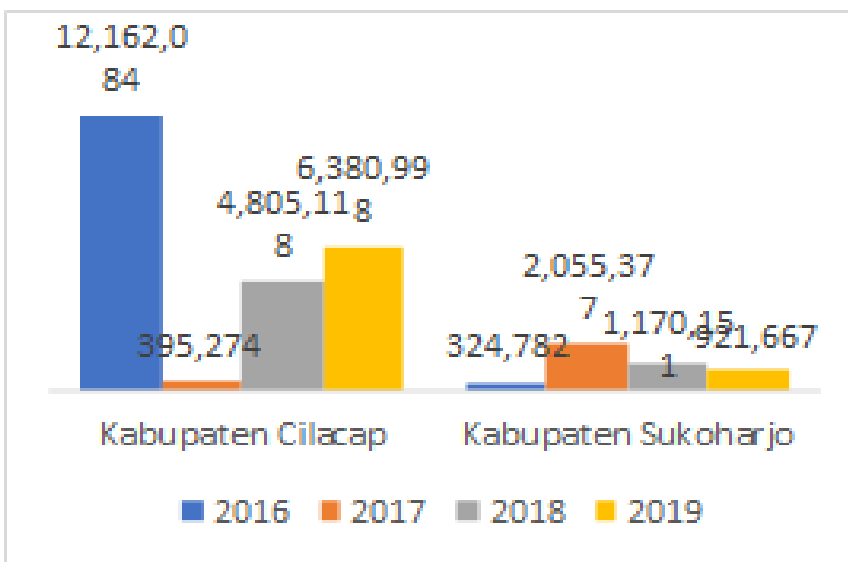

Gambar 2. Pertumbuhan Realisasi Penanaman Modal Dalam Negeri di Kabupaten Cilacap dan Kabupaten Sukoharjo

Seperti diketahui investasi berbanding terbalik terhadap suku bunga, apabila suku bunga rendah maka investasi akan tinggi dan sebaliknya, hal ini diduga sebagai pemicu perubahan investasi (Sukirno, 2008:125). Selama 4 tahun terakhir PMDN cenderung fluktuatif. Perubahan yang siginfikan terhadap PMDN dapat dikatakan bahwa kondisi ekonomi dan fenomena yang sedang terjadi sehingga investor dan juga iklim investasi menjadi menurun sehingga berdampak pada kabupaten di Provinsi Jawa Tengah. Proporsi naik turunnya pertumbuhan investasi dalam negeri di Kabupaten Cilacap dan Kabupaten Sukoharjo tidak berarti pembangunan ekonomi berjalan lambat tetapi bagaimana efisiensi serta produktivitas dari investasi tersebut. Kondisi ini dapat menjadi peluang bagi pemerintah agar dapat menarik peminat investor untuk menamkan modalnya dengan meningkatkan fasilitas yang ada sehingga memudahkan para investor untuk menanamkan modalnya.

Dari setiap kabupaten di provinsi memiliki potensi regional yang dapat dijaga dan di kembangkan agar memiliki daya saing kompetitif maupun komparatif, karena suatu pertumbuhan ekonomi tidak hanya bergantung dari satu sektor saja. Kesemua sektor memegang peranan penting juga dalam pertumbuhan perekonomian suatu daerah.

Dari latar belakang diatas seperti diatas, peneliti akan menguraikan baik secara menyeluruh maupun secara terperinci, bagaimana perkembangan sektor ekonomi dalam pembangunan ekonomi serta bagaimana pengaruh sektor basis dan non basis terhadap investasi di Kabupaten Cilacap dan Kabupaten Sukoharjo.

\section{Kajian Pustaka \\ Pertumbuhan Ekonomi.}

Pertumbuhan ekonomi di definisikan sebagai pertumbuhan dari pendapatan nasional yang terjadi di suatu Negara dari tahun ke tahun. Pertumbuhan ekonomi juga merupakan indikator yang amat penting dalam melakukan analisis tentang pembangunan ekonomi yang terjadi di suatu wilayah (Sukirno, 2004, p. 178) 
Pertumbuhan ekonomi harus mencerminkan pertumbuhan output perkapita. Dengan pertumbuhan per kapita, berarti terjadi pertumbuhan upah riil dan meningkatnya standar hidup. Jika pertumbuhan terjadi di suatu daerah, maka akan memberikan dampak bagi daerah di sekitarnya. Prioritas anggaran sangat dibutuhkan oleh sektor ekonomi potensial yang diharapkan dapat mendorong kemajuan sektor-sektor lainnya (Dermurger dalam Devi and Yasa, 2018). Kemajuan sektor lainnya dapat mendorong investasi dan mendorong pembangunan.

\section{Pembangunan Ekonomi Daerah}

Pembangunan ekonomi bergantung dari pertumbuhan ekonomi (economic growth) dimana pembangunan ekonomi mendorong dalam tumbuhanya ekonomi dan sebaliknya pula, ekonomi memperlancar dalam proses pembangunan ekonomi (Hadi, 2012). Melalui upaya pembangunan daerah, dapat diambil aspek-aspek yang memiliki potensi ekonomi untuk dikembangkan. Dalam kerangka pembangunan daerah, potensi ekonomi merupakan adanya kesanggupan maupun kemampuan dalam bidang ekonomi di suatu daerah untuk membangun daerahnya masing-masing.

\section{Teori Tricle Down Effect.}

Hirschman (Arsyad, 2010) berpendapat bahwa investasi merupakan salah satu kegiatan ekonomi yang dapat diutamakan untuk mempercepat laju pertumbuhan ekonomi dalam trickle down effect karena kesempatan investasi, lapangan kerja, dan upah buruh relative lebih banyak terdapat di pusat-pusat pertumbuhan sesuai dengan titik-titik pertumbuhan yang dikemukakan oleh Hirschman.

\section{Investasi.}

Investasi merupakan pengeluraran atau perbelanjaan penanaman modal untuk membeli barangbarang modal serta perlengkapan produksi untuk menambah kemampuan memproduksi barang dan jasa yang tersedia dalam perekonomian. Investasi bukan banya untuk memaksimalkan output, tetapi untuk menentukan distribusi tenaga kerja dan pendapatan, pertumbuhan serta kualitas penduduk serta teknologi. (Sukirno dalam Siwi, 2018)

Sejalan dengan teori yang dikemukakan oleh Harrod-Domar bahwa pentingnya investasi dapat menciptakan

pertumbuhan ekonomi yang berkelanjutan. Tujuan dari adanya penanaman modal akan dapat tercapai apabila terdapat faktor yang menghambat iklim penanaman modal dappat diatasi. Dengan adanya perbaikan faktor penunjang, maka diharapkan realisasi penanaman modal akan membaik secara signifikan.

\section{Strategi Pembangunan Ekonomi Daerah.}

Dalam (Arsyad,2004) mengemukan strategi pembangunan dibagi menjadi dua yaitu strategi pembangunan siembang dan strategi pembangunan tidak seimbang. Pembangunan seimbang dapat diartikan sebagai pengembangan berbagai jenis industri secara bersamaan sehingga dapat menciptakan pasar. Pembangunan seimbang ini dapat pula diartikan sebagai keseimbangan pembangunan di berbagai sektor. Sehingga, strategi pembangunan seimbang ini mengharuskan adanya pembangunan yang serentak dan harmonis di berbagai sektor ekonomi.

\section{Sektor Potensial dalamPengembangan Wilayah}

Wilayah dengan potensi yang mengalami perkembangan lebih besar maka akan berkembang lebih pesat yang kemudian dapat berdampak pada wilayah sekitarnya.

Dalam pengembangan wilayah, pengembangan tidak dapat dilakukan serentak pada semua sektor perekonomian namun diprioritaskan pada pengembangan sektor-sektor dengan potensi yang cukup besar perkembangannya dan diharapkan dapat tumbuh dan berkembang pesat yang akan merangsang sektor lain untuk mengimbangi perkembangan sektor potensial tersebut.

\section{METODE PENELITIAN Jenis Penelitian}

Jenis data yang digunakan dalam penelitian ini adalah data sekunder atau kuantitatif. Data diperoleh berdasarkan data yang tersedia dan dipublikasikan oleh Badan Pusat Statistik Provinsi Jawa Tengah, Kabupaten Cilacap, dan Kabupaten Sukoharjo. Jenis data yang digunakan adalah data time series dalam kurun waktu 4 tahun yaitu 2016-2019 dan interpolasi data untuk diregresikan.

\section{Metode Analisis}

Penelitian berikut ini dilakukan dengan menggunakan metode analisis kuantitatif yaitu dengan menggunakan alat analisis Location Quotient (LQ), Analisis Regresi Linier Sederhana, Shift-Share, dan Tipologi Klasen. Sedangkan proses dalam pengolahan data dilakukan dengan cara menggunakan program spss 13.0 sebagai alat dalam mengolah data.

\section{Analisis Regresi Sederhana}

Analisis regeresi linier sederhana merupakan sebuah hubungan fungsional maupun kausal dalam satu variabel independen dengan satu variabel dependen. Alat anaslis yang digunakan merupakan analisis regresi linier sederhana yang dihasilkan dari persamaan yang bersifat linier dan melibatkan satu variabel bebsa untuk digunakan sebagai alat prediksi besarnya nilai variabel tergantung (Sugiyono, 2017). berikut :

Rumus regresi linier sederhana adalah sebagai

a. Sektor basis

$\mathbf{Y}_{1}=\boldsymbol{\alpha}+\boldsymbol{\beta} \mathbf{X}_{1}$

Keterangan: 
Margaretha Dwi Suprapti Setyaningrum, Niniek Imaningsih dan Riko Setya Wijaya, Analisis Sektor Ekonomi Serta Pengaruh Investasi terhadap Sektor Basis Dan Non Basis 2 Kabupaten Di Provinsi Jawa Tengah

$\mathrm{Y}_{1}=$ Variabel dependen (PDRB sektor basis)

$\mathrm{X}=$ Variabel independen $(\mathrm{PMDN})$

$\alpha \quad=$ Konstanta (nilai $\mathrm{Y} 1$ apabila $\mathrm{X}=0$ )

$\beta=$ Koefisien regresi

b. Sektor non basis

$\mathbf{Y}_{2}=\boldsymbol{\alpha}+\boldsymbol{\beta} \mathbf{X}_{1}$

Keterangan:

Y2 = Variabel dependen (PDRB sektor non basis)

$\mathrm{X}=$ Variabel independen (PMDN)

$\alpha=$ Konstanta (nilai $Y 2$ apabila $\mathrm{X}=0$ )

$\beta=$ Koefisien regresi

\section{HASIL DAN PEMBAHASAN \\ Hasil Location Quotient (LQ)}

Tabel 1. Hasil Perhitungan Location Quetient Kabupaten Cilacap.

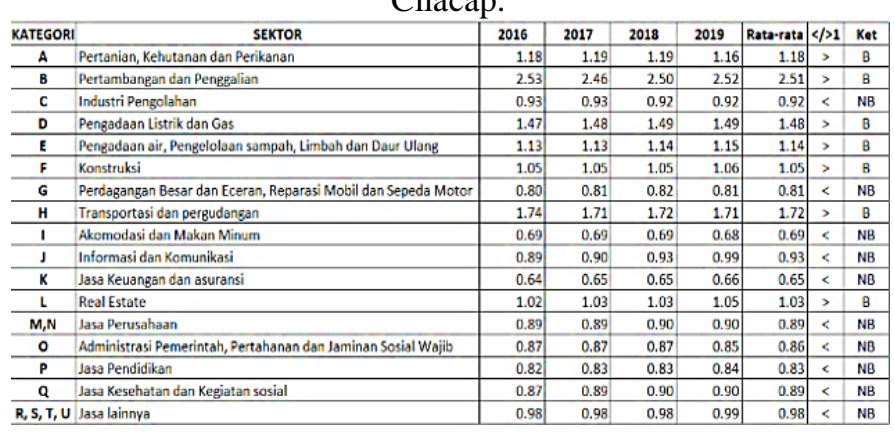

Berdasarkan pada perhitungan tabel diatas, jika dilihat dari nilai Location Quetient terdapat tujuh sektor yang mampu menjadi sektor basis di Kabupaten Cilacap dan sepuluh sektor lainnya termasuk dalam sektor non basis serta memiliki rata-rata. Ketujuh sektor basis tersebut adalah sektor pertanian, kehutanan, dan perikanan dengan rata-rata 1,18 ; sektor pertambangan dan penggalian dengan rata-rata 2,51; sektor pengadaan listrik dan gas dengan rata-rata 1,48 ; sektor pengadaan air, pengelolaan sampah, limbah dan daur ulang dengan rata-rata 1,14 ; sektor konstruksi dengan rata-rata 1,05 ; sektor transportasi dan pergudangan dengan rata-rata 1,72; dan sektor real estate dengan rata-rata 1,03 . Sektor Pertambangan dan Penggalian menjadi sektor dengan rata-rata terbesar di Kabupaten Cilacap sebesar 2,51. Hal ini dapat disebabkan karena kekayaan sumber daya alam Kabupaten Cilacap akan bahan pertambangan dan penggaliannya seperti minyak dan gas bumi, batu bara, emas, pasir besi, bentonite, hingga tanah urung. Dengan nilai Location Quetient lebih dari 1, maka ketujuh sektor tersebut menjadi basis atau menjadi sumber pertumbuhan serta memiliki keunggulan komparatif sehingga hasilnya tidak hanya dapat memenuhi kebutuhan di Kabupaten Cilacap tetapi dapat digunakan sebagai kegiatan ekspor ke luar wilayah.
Tabel 2. Hasil Perhitungan Location Quetient Kabupaten

\begin{tabular}{|c|c|c|c|c|c|c|c|}
\hline SEKTOR & 2015 & 2017 & 2018 & 2019 & Rata-rata & \langle\rangle $\mid$ & Ket \\
\hline Pertanian, Kehutanan dan Perikanan & 0.66 & 0.64 & 0.63 & 0.63 & 0.64 & $<$ & NB \\
\hline Pertambangan dan Penggalian & 0.18 & 0.17 & 0.17 & 0.16 & 0.17 & $<$ & NB \\
\hline Industri Pengolahan & 1.12 & 1.11 & 1.13 & 1.13 & 1.12 & $>$ & $B$ \\
\hline Pengadaan Listrik dan Gas & 1.24 & 1.20 & 1.19 & 1.17 & 1.20 & $>$ & $B$ \\
\hline Pengadaan air, Pengelolaan sampah, Limbah dan Daur Ulang & 0.57 & 0.54 & 0.54 & 0.54 & 0.55 & $<$ & NB \\
\hline Konstruksi & 0.65 & 0.62 & 0.62 & 0.62 & 0.63 & $<$ & NB \\
\hline Perdagangan Besar dan Eceran, Reparasi Mobil dan Sepeda Motor & 1.33 & 1.28 & 1.26 & 1.25 & 1.28 & $>$ & $B$ \\
\hline Transportasi dan pergudangan & 1.11 & 1.09 & 1.09 & 1.07 & 1.09 & $>$ & $B$ \\
\hline Akomodasi dan Makan Minum & 1.22 & 1.19 & 1.18 & 1.15 & 1.18 & $>$ & $B$ \\
\hline Informasi dan Komunikasi & 1.33 & 1.26 & 1.24 & 1.21 & 1.26 & $>$ & $B$ \\
\hline Jasa Kevangan dan asuransi & 0.46 & 1.28 & 1.28 & 1.27 & 1.07 & $>$ & B \\
\hline Real Estate & 1.35 & 1.33 & 1.34 & 1.34 & 1.34 & $>$ & $B$ \\
\hline Lasa Perusahaan & 1.08 & 1.05 & 1.04 & 1.02 & 1.05 & $>$ & $B$ \\
\hline Administrasi Pemerintah, Pertahanan dan Jaminan Sosial Wajib & 0.85 & 0.82 & 0.83 & 0.82 & 0.83 & $<$ & NB \\
\hline Jasa Pendidikan & 0.98 & 0.96 & 0.95 & 0.95 & 0.96 & $<$ & NB \\
\hline \begin{tabular}{|l|} 
Jasa Kesehatan dan Kegiatan sosial \\
\end{tabular} & 1.13 & 1.09 & 1.09 & 1.09 & 1.10 & $>$ & $B$ \\
\hline Lasa lainnya & 0.92 & 0.87 & 0.64 & 0.86 & 0.82 & $<$ & NB \\
\hline
\end{tabular}

Berdasarkan pada perhitungan tabel diatas, jika dilihat dari nilai Location Quetient terdapat sepuluh sektor yang menjadi sektor basis di Kabupaten Sukoharjo dan tujuh sektor lainnya termasuk dalam sektor non basis serta memiliki rata-rata. Kesepuluh sektor basis tersebut adalah sektor industi pengolahan dengan rata-rata 1,12. Hal ini disebabkan karena produksi sektor industri pengolahan di Kabupaten Sukoharjo telah mampu untuk memenuhi kebutuhan sektornya serta dapat memenuhi kebutuhan daerah lainnya. Misalnya dengan adanya industri sepatu dan peralatan olah raga, industri pengolahan kayu, industri tekstil dan garmen, industry kertas dan karton Kabupaten Sukoharjo yang dapat mengekspor hasilnya ke berbagai daerah disekitarnnya; sektor pengadaan listrik dan gas dengan rata-rata sebesar 1,20. Hal ini dikarenakan semakin meluasnya perumahan dan perindustrian yang ada di Kabupaten Sukoharjo, sehingga untuk memenuhi kebutuhan penerangan; sektor perdagangan besar dan eceran, reparasi mobil dan motor dengan rata-rata 1,28 ; sektor transportasi dan pergudangan dengan rata-rata 1,09; sektor akomodasi dan makan minum dengan ratarata 1,18; sektor informasi dan komunikasi dengan ratarata 1,26; jasa keuangan dan asuranasi dengan rata-rata 1,07; sektor real estate dengan rata-rata 1,34 merupakan sektor dengan rata-rata terbesar. Hal ini dikarenakan adanya pertumbuhan aktivitas ekonomi untuk sektor bangunan di Kabupaten Sukoharjo sebagai tempat hunian maupun penentuan lokasi bisnis; sektor jasa perusahaan dengan rata-rata 1,05 ; kemudian sektor jasa kesehatan dengan rata-rata 1,20. Dengan nilai Location Quetient lebih dari 1, maka kesepuluh sektor tersebut menjadi basis atau menjadi sumber pertumbuhan serta memiliki keunggulan komparatif sehingga hasilnya tidak hanya dapat memenuhi kebutuhan di Kabupaten Sukoharjo tetapi dapat digunakan sebagai kegiatan ekspor ke luar wilayah. Ketujuh sektor lainnya termasuk dalam sektor non basis dengan rata-rata terkecil 0.17 pada sektor pertambangan dan penggalian. Sektor non basis di Kabupaten Sukoharjo masih belum dapat memenuhi kebutuhan sektor tersebut dalam daerah hingga diperlukan pasokan hingga kegiatan impor dari luar wilayah kabupaten Sukoharjo. 


\section{Analisis Regresi Sederhana}

Berikut hasil regresi untuk mengetahui pengaruh Investasi (PMDN) ( $\left.\mathrm{X}_{1}\right)$; PDRB Sektor Basis Kab. Cilacap $\left(\mathrm{Y}_{1.1}\right)$; PDRB Sektor non Basis Kab. Cilacap $\left(\mathrm{Y}_{1.2}\right)$; PDRB Sektor Basis Kab. Sukoharjo ( $\left.\mathrm{Y}_{2.1}\right)$; PDRB Sektor non Basis Kab. Sukoharjo $\left(\mathrm{Y}_{2.2}\right)$, Hasil regresi bisa dilihat pada tabel berikut:

\begin{tabular}{|l|l|}
\hline Variabel Independent & $\begin{array}{l}\text { Variabel Dependent } \\
\mathrm{X}=\text { Investasi (PMDN) }\end{array}$ \\
\hline $\begin{array}{l}\text { PDRB Sektor Basis Kab. } \\
\text { Cilacap (Y.1) }\end{array}$ & $\mathrm{Y}=252025+5.5182 \mathrm{X}$ \\
\hline $\begin{array}{l}\text { PDRB Sektor non Basis Kab. } \\
\left.\text { Cilacap(Y } \mathrm{Y}_{1.2}\right)\end{array}$ & $\mathrm{Y}=159262-0.609 \mathrm{X}$ \\
\hline $\begin{array}{l}\text { PDRB Sektor Basis Kab. } \\
\text { Sukoharjo (Y.1) }\end{array}$ & $\mathrm{Y}=276218+0.0494 \mathrm{X}$ \\
\hline $\begin{array}{l}\text { PDRB Sektor non Basis Kab. } \\
\text { Sukoharjo (Y2.2) }\end{array}$ & $\mathrm{Y}=126407-0.3211 \mathrm{X}$ \\
\hline
\end{tabular}

Berdasarkan pada tabel diatas, maka didapatkan persamaan regresi linier sebagai berikut:

1. $\mathrm{a}=252025,0$, berarti apabila Investasi (PMDN) bernilai 0 , maka besarnya pertumbuhan sektor basis di Kabupaten Cilacap adalah sebesar 25.2025 Juta. $\mathrm{X}=5.5182$, berati apabila Investasi (PMDN) meningkat sebesar 1 Juta, maka pertumbuhan sektor basis akan meningkat sebesar 5.5182 Juta. Regresi PDRB sektor basis Kabupaten Cilacap bernilai positif.

2. $\mathrm{a}=159262,7$, berarti apabila Investasi (PMDN) bernilai 0 , maka besarnya pertumbuhan sektor non basis di Kabupaten Cilacap adalah sebesar 159262 Juta. $X=-0,0609$, atau $-0,060$ berati apabila Investasi (PMDN) meningkat sebesar 1 Juta, maka pertumbuhan sektor non basis akan mengalami penurunan sebesar 0,060 juta. Regresi PDRB sektor non basis Kabupaten Cilacap bernilai negatif.

3. $\mathrm{a}=276218,8$, berarti apabila Investasi (PMDN) bernilai 0 , maka besarnya pertumbuhan sektor basis di Kabupaten Sukoharjo adalah sebesar 276218,8 Juta. $X=0,049$, berati apabila Investasi (PMDN) meningkat sebesar 1 Juta, maka pertumbuhan sektor basis akan meningkat sebesar 0,049 Juta. Regresi PDRB sektor basis Kabupaten Sukoharjo bernilai positif.

4. $\mathrm{a}=1264079$, berarti apabila Investasi (PMDN) bernilai 0 , maka besarnya pertumbuhan sektor non basis di Kabupaten Sukoharjo adalah sebesar 126 Juta. $X=-0,3211$, atau $-0,32$ berati apabila Investasi (PMDN) meningkat sebesar 1 Juta, maka pertumbuhan sektor non basis akan mengalami penurunan sebesar 0,32 Juta. Regresi PDRB sektor non basis Kabupaten Sukoharjo bernilai negatif.

\section{Uji Asumsi Klasik \\ Uji Autokorelasi}

Berdasarkan hasil regresi terdapat adanya gejala autorkorelasi pada model, terlihat nilai Durbin Watson dapat disimpulkan terjadi masalah autokorelasi. Maka akan diperbaiki dengan menggunakan metode CochraneOrcutt (C-O). Metode ini adalah alternatif untuk mendapatkan nilai struktur autokorelasi $(\rho)$ yang tidak diketahui. Uji ini menggunakan nilai estimasi residual untuk menghitung $\rho$. Setelah nilai $\rho$ diketahui maka akan dilakukan transformasi masing-masing variabel. Hasilnya akan dilakukan regresi kembali dan hasil regresi diasumsikan sudah tidak mengandung masalah autokorelasi. (Purnamasari, 2015)

Berdasarkan perbaikan output menggunakan metode Cochrane-Orcutt (C-O), maka dalam model regresi ini tidak terjadi gejala autokorelasi karena nilai DW tes yang diperoleh adalah sebegai berikut:

Tabel nilai Durbin Watson setelah menggunakan metode Cochrane-Orcutt (C-O)

\begin{tabular}{|c|c|c|c|}
\hline Variabel & $\begin{array}{c}\text { Nilai } \\
\text { DW test }\end{array}$ & $\begin{array}{c}\text { Ketentuan } \\
\text { daerah }\end{array}$ & Keterangan \\
\hline $\begin{array}{l}\text { PDRB Sektor Basis } \\
\text { Kab. Cilacap }\left(\mathrm{Y}_{1.1}\right)\end{array}$ & 2.364 & \multirow{4}{*}{$\begin{array}{l}0-1.1062 \text { (terjadi } \\
\text { autokorelasi) } \\
1.1062-1.3709 \\
\text { (daerah ragu-ragu) } \\
1.3709-2.6291 \\
\text { (tidak terjadi } \\
\text { autokorelasi) } \\
2.6291-2.9838 \\
\text { (daerah ragu-ragu) } \\
2.8938-4 \text { (terjadi } \\
\text { autokorelasi) }\end{array}$} & Tidak terjadi Autokorelasi \\
\hline $\begin{array}{l}\text { PDRB Sektor non } \\
\text { Basis Kab. Cilacap } \\
\left(\mathrm{Y}_{1.2}\right)\end{array}$ & 1.971 & & Tidak terjadi Autokorelasi \\
\hline $\begin{array}{l}\text { PDRB Sektor Basis } \\
\text { Kab. Sukoharjo } \\
\left(\mathrm{Y}_{2.1}\right)\end{array}$ & 2.153 & & Tidak terjadi Autokorelasi \\
\hline $\begin{array}{l}\text { PDRB Sektor non } \\
\text { Basis Kab. } \\
\text { Sukoharjo }\left(\mathrm{Y}_{2.2}\right)\end{array}$ & 2.046 & & Tidak terjadi Autokorelasi \\
\hline
\end{tabular}

Dalam persamaan regresi, jumlah variabel bebas (k) adalah 1 dan banyaknya data (n) adalah 16 sehingga diperoleh nilai DW tabel adalah sebesar dalam tabel dengan nilai $\mathrm{dL}=1.1062 \mathrm{dan} \mathrm{du}=1.3709$. Dapat dilihat dalam tabel bahwa tidak terdapat autokorelasi karena hail nilai DW yang diperoleh berada diantara nilai $\mathrm{dU}=1,3709$ dan $4 \mathrm{dU}=2,6291$ yang berarti berada pada daerah tidak terjadi autorkorelasi .

\section{Uji Multikolinieritas}

Hasil Uji Multikolinieritas

\begin{tabular}{|l|c|c|c}
\hline \multicolumn{1}{|c|}{ Variabel } & VIF (X) & Ketentuan & Keterangan \\
\hline $\begin{array}{l}\text { PDRB Sektor } \\
\text { Basis Kab. } \\
\text { Cilacap (Y.1) }\end{array}$ & 1,000 & $<10$ & $\begin{array}{c}\text { Tidak terjadi } \\
\text { Multikolinieritas }\end{array}$ \\
\hline $\begin{array}{l}\text { PDRB Sektor } \\
\text { non Basis Kab. } \\
\text { Cilacap (Y.2) }\end{array}$ & 1,000 & $<10$ & $\begin{array}{c}\text { Tidak terjadi } \\
\text { Multikolinieritas }\end{array}$ \\
\hline $\begin{array}{l}\text { PDRB Sektor } \\
\begin{array}{l}\text { Basis Kab. } \\
\text { Sukoharjo (Y.1) }\end{array}\end{array}$ & 1,000 & $<10$ & $\begin{array}{c}\text { Tidak terjadi } \\
\text { Multikolinieritas }\end{array}$ \\
\hline $\begin{array}{l}\text { PDRB Sektor } \\
\text { non Basis Kab. } \\
\text { Sukoharjo (Y.2) }\end{array}$ & 1,000 & $<10$ & $\begin{array}{c}\text { Tidak terjadi } \\
\text { Multikolinieritas }\end{array}$ \\
\hline
\end{tabular}

Sumber: Lampiran (Output SPSS)

Hasil uji multikolinearitas di atas, nilai VIF yang di dapat <10 sehingga dapat disimpulkan bahwa tidak terdapat masalah multikolinearitas. 


\section{Uji Hetroskedastitas}

Tabel 4.9

Hasil uji Heterokedastisitas dengan Korelasi Rank Spearman

\begin{tabular}{|l|c|c|l}
\hline \multicolumn{1}{|c|}{ Variabel } & Sig 2-tailed (X) & Ketentuan & \multicolumn{1}{c}{ Keterangan } \\
\hline $\begin{array}{l}\text { PDRB Sektor } \\
\text { Basis Kab. } \\
\text { Cilacap (Y.1) }\end{array}$ & 0,092 & $\geq 0,05$ & $\begin{array}{l}\text { Tidak Terjadi } \\
\text { Heterokedastitas }\end{array}$ \\
\hline $\begin{array}{l}\text { PDRB Sektor non } \\
\text { Basis Kab. } \\
\text { Cilacap (Y.2) }\end{array}$ & 0,633 & $\geq 0,05$ & $\begin{array}{l}\text { Tidak Terjadi } \\
\text { Heterokedastitas }\end{array}$ \\
\hline $\begin{array}{l}\text { PDRB Sektor } \\
\text { Basis Kab. } \\
\text { Sukoharjo (Y.1) }\end{array}$ & 0,092 & $\geq 0,05$ & Tidak Terjadi \\
\hline $\begin{array}{l}\text { PDRB Sektor non } \\
\text { Basis Kab. } \\
\text { Sukoharjo (Y.2) }\end{array}$ & 0,231 & $\geq 0,05$ & Tidak Terjadi \\
Sumber: Lampiran (Output SPSS) & & Heterokedastitas \\
\hline
\end{tabular}

Untuk menganalisis model ini dapat melihat output Unstandardized Residual. sig. nya harus lebih dari 0.05 yang artinya terbebas dari model heteroskesdastitas. Maka dalam tabel diatas tidak terjadi heterokedastisitas.

\section{Uji Simultan (Uji F)}

\section{Hasil Tabel Uji F}

\begin{tabular}{c|c|l|c|c|c|}
\hline Model & Df & \multicolumn{1}{|c|}{ Variabel Y/X } & F & $\begin{array}{c}\text { Tingkat } \\
\text { Signifiknsi } \\
\text { Investasi } \\
(\mathrm{X})\end{array}$ & $\begin{array}{c}\text { Keterangan } \\
\alpha=0,05\end{array}$ \\
\hline 1 & 1 & $\begin{array}{l}\text { PDRB Sektor Basis Kab. } \\
\text { Cilacap (Y1.1) }\end{array}$ & 14,025 & 0,002 & Signifikan \\
\hline 2 & 14 & $\begin{array}{l}\text { PDRB Sektor non Basis } \\
\text { Kab. Cilacap (Y.2) }\end{array}$ & 20,793 & 0,000 & Signifikan \\
\hline 3 & 15 & $\begin{array}{l}\text { PDRB Sektor Basis Kab. } \\
\text { Sukoharjo (Y2.1 }\end{array}$ & 30,597 & 0,000 & Signifikan \\
\hline 4 & & $\begin{array}{l}\text { PDRB Sektor non Basis } \\
\text { Kab. Sukoharjo (Y2.2) }\end{array}$ & 8,998 & 0,010 & Signifikan \\
\hline
\end{tabular}

Sumber: Lampiran (Output SPSS)

Dari tabel diatas persamaan model 1 sampai 4 diperoleh nilai Fhitung sebesar 14,025; 20,793; 30,597; 8,998 dengan tingkat signifikansi sebesar 0,$002 ; 0,000$; 0,$000 ; 0,010$ sedangkan nilai Ftabel $(\alpha=0,05)$ dengan df1 1 (k); dan df2 14 (n-k-1) diperoleh nilai $F$ tabel sebesar 4,600. Dari hasil tersebut diketahui bahwa nilai Fhitung $\geq$ Ftabel. Maka dapat disimpulkan secara simultan variabel Investasi (X) berpengaruh secara signifikan dan berarah positif terhadap PDRB Sektor basis $\left(\mathrm{Y}_{1.1}\right)$; $\left(\mathrm{Y}_{2.1}\right)$ dan PDRB sektor non basis $\left(\mathrm{Y}_{1.2}\right)$; $\left(\mathrm{Y}_{2.2}\right)$ di Kabupaten Cilacap dan Kabupaten Sukoharjo.

\section{Uji Koefisien Determinasi $\mathbf{R}^{\mathbf{2}}$}

Berdasarkan hasil pengujian menunjukkan nilai

R2 dan dijelaskan sebagai berikut :

1. Dengan nilai R2 sebesar 0,50 atau $50 \%$. Hal ini berarti bahwa Investasi (PMDN) mampu menjelaskan PDRB Sektor Basis Kabupaten Cilacap sebesar 50\%, sedangkan sisanya sebesar $50 \%$ dijelaskan oleh variabel lain diluar model.
2. Dengan nilai R2 sebesar 0,598 atau $60 \%$. Hal ini berarti bahwa Investasi (PMDN) mampu menjelaskan PDRB Sektor non Basis Kabupaten Cilacap sebesar $60 \%$, sedangkan sisanya sebesar $40 \%$ dijelaskan oleh variabel lain diluar model.

3. Dengan nilai R2 sebesar 0,686 atau $70 \%$. Hal ini berarti bahwa Investasi (PMDN) mampu menjelaskan PDRB Sektor Basis Kabupaten Sukoharjo sebesar $70 \%$ sedangkan sisanya sebesar $30 \%$ dijelaskan oleh variabel lain diluar model.

4. Dengan nilai R2 sebesar 0,391 atau $40 \%$. Hal ini berarti bahwa Investasi (PMDN) mampu menjelaskan PDRB sektor non basis Kabupaten Sukoharjo sebesar $40 \%$ sedangkan sisanya sebesar $60 \%$ dijelaskan oleh variabel lain diluar model.

\section{Analisis Shift Share}

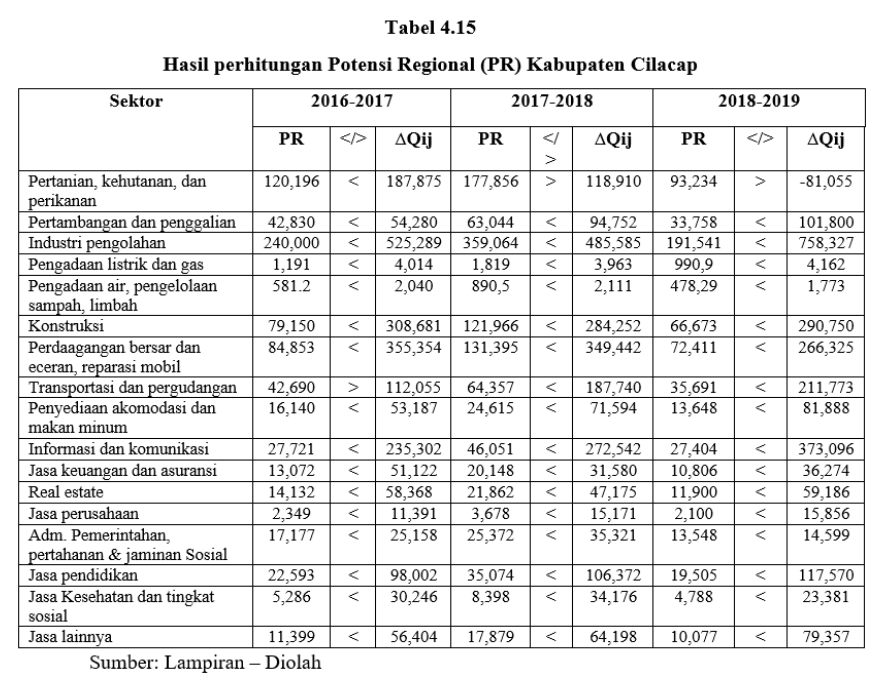

Berdasarkan pada perhitungan Analisis Shift Share (Potential Regional) dapat dilihat di Kabupaten Cilacap tahun 2016-2017 terdapat 16 sektor yang dapat mendorong pertumbuhan PDRB di Jawa Tengah. Sedangkan di tahun 2017-2019 memiliki 16 sektor yang sama dalam sektor yang mendorong pertumbuhan PDRB di Jawa Tengah yaitu Sektor Pertambangan dan penggalian; Industri pengolahan; Pengadaan listrik dan gas; Pengadaan air, pengolahan sampah, limbah dan daur ulang; Konstruksi; Perdagangan besar dan eceran, reparasi mobil dan motor; Transportasi dan pergudangan; Penyediaan akomodasi dan makan minum; Informasi dan komunikasi; Jasa keuangan dan asuransi; Real estate; Jasa Perusahaan; Adm. Pemerintahan, pertahanan dan jaminan sosial wajib; Jasa pendidikan; Jasa kesehatan dan kegiatan sosial; dan Jasa lainnya. 


\begin{tabular}{|c|c|c|c|c|c|c|c|c|c|}
\hline \multirow{2}{*}{ Sektor } & \multicolumn{3}{|c|}{ 2016-2017 } & \multicolumn{3}{|c|}{ 2017-2018 } & \multicolumn{3}{|c|}{ 2018-2019 } \\
\hline & PR & $\langle>$ & $\Delta \mathbf{Q i j}$ & PR & $\langle\nabla\rangle$ & $\Delta \mathbf{Q i j}$ & PR & $\langle>\rangle$ & $\Delta \mathbf{Q i j}$ \\
\hline $\begin{array}{l}\begin{array}{l}\text { Pertanian, kehutanan, dan } \\
\text { perikanan }\end{array} \\
\end{array}$ & 36,895 & $>$ & 22,281 & 53,667 & $>$ & 13,696 & 27,833 & $<$ & 70,077 \\
\hline $\begin{array}{l}\text { Pertambangan dan } \\
\text { penggalian }\end{array}$ & 1,705 & $>$ & $-2,497$ & 2,388 & $>$ & 2,234 & 1,260 & $>$ & $-1,513$ \\
\hline \begin{tabular}{|l} 
Industri pengolahan \\
\end{tabular} & $\begin{array}{c}159,12 \\
3\end{array}$ & $<$ & 536,448 & $\begin{array}{c}242,99 \\
7\end{array}$ & $<$ & $\begin{array}{c}599,79 \\
8\end{array}$ & $\begin{array}{c}133,28 \\
7\end{array}$ & $<$ & $\begin{array}{c}556,83 \\
5 \\
\end{array}$ \\
\hline \begin{tabular}{|l} 
Pengadaan listrik dan gas \\
\end{tabular} & 551,49 & $>$ & 1,281 & $\begin{array}{c}827,02 \\
5\end{array}$ & $<$ & 1,495 & 446,26 & $<$ & 1,734 \\
\hline $\begin{array}{l}\text { Pengadaan air, pengelolaan } \\
\text { sampah, limbah }\end{array}$ & 159,98 & $<$ & 376 & 240,03 & $<$ & 389 & 128,92 & $<$ & 658 \\
\hline \begin{tabular}{|l|} 
Konstruksi \\
\end{tabular} & 26,739 & $<$ & 96,864 & 41,009 & $<$ & 87,706 & 22,311 & $<$ & 94,687 \\
\hline $\begin{array}{l}\text { Perdaagangan bersar dan } \\
\text { eceran, reparasi mobil } \\
\end{array}$ & 77,364 & $<$ & 215,630 & $\begin{array}{c}116,95 \\
8\end{array}$ & $<$ & $\begin{array}{c}206,24 \\
8\end{array}$ & 63,040 & $<$ & $\begin{array}{c}258,39 \\
8\end{array}$ \\
\hline \begin{tabular}{|l|}
$\begin{array}{l}\text { Transportasi dan } \\
\text { pergudangan }\end{array}$ \\
\end{tabular} & 14,947 & $<$ & 61,467 & 23,116 & $<$ & 63,802 & 12,770 & $<$ & 70,906 \\
\hline $\begin{array}{l}\text { Penyediaan akomodasi dan } \\
\text { makan minum }\end{array}$ & 15,581 & $<<$ & 53,320 & 23,815 & $<$ & 67,135 & 13,175 & $<$ & 72,891 \\
\hline \begin{tabular}{|l|} 
Informasi dan komunikasi \\
\end{tabular} & 22,678 & $<$ & 137,465 & 36,231 & $<$ & $\begin{array}{c}140,09 \\
8\end{array}$ & 20,557 & $<$ & $\begin{array}{c}158,00 \\
4\end{array}$ \\
\hline \begin{tabular}{|l|l} 
Jasa keuangan dan asuransi \\
\end{tabular} & 5,156 & $<<$ & 572,754 & 22,430 & $<$ & 35,276 & 12,031 & $<$ & 30,931 \\
\hline \begin{tabular}{|l|} 
Real estate \\
\end{tabular} & 10,255 & $<<$ & 43,421 & 15,892 & $<$ & 39,130 & 8,716 & $<$ & 41,123 \\
\hline \begin{tabular}{|l|} 
Jasa perusahaan \\
\end{tabular} & 1,571 & $<$ & 7,069 & 2,446 & $<$ & 7,976 & 1,367 & $<$ & 9,443 \\
\hline $\begin{array}{l}\text { Adm. Pemerintahan, } \\
\text { pertahanan \& jaminan } \\
\text { Sosial }\end{array}$ & 9,210 & $<$ & 13,443 & 13,603 & $<$ & 22,680 & 7,314 & $<$ & 20,641 \\
\hline Jasa pendidikan & 14,786 & $<$ & 58,456 & 22,805 & $<$ & 62,088 & 12,857 & $<$ & 75,235 \\
\hline $\begin{array}{l}\text { Jasa Kesehatan dan tingkat } \\
\text { sosial }\end{array}$ & \begin{tabular}{|l|}
3,760 \\
\end{tabular} & $<$ & 16,290 & 5,837 & $<$ & 18,547 & 3,257 & $<$ & 17,830 \\
\hline Jasa lainnya & 5,866 & $<<$ & 21,889 & 9,013 & $<$ & $-68,172$ & 3,723 & $<$ & $\begin{array}{c}134,49 \\
6\end{array}$ \\
\hline
\end{tabular}

Berdasarkan pada perhitungan Analisis Shift Share (Potential Regional) dapat dilihat di Kabupaten Sukoharjo tahun 2016-2017 terdapat 14 sektor yang dapat mendorong pertumbuhan PDRB di Jawa Tengah. Sedangkan di tahun 2017-2018 memiliki 3 sektor yang mengambat pertumbuhan PDRB di Jawa Tengah yaitu Sektor Pertanian, kehutanan dan perikanan; pertambangan dan penggalian; serta Jasa lainnya. Pada tahun 2018-2019 memiliki 16 sektor yang dapat mendorong pertumbuhan PDRB di Jawa Tengah termasuk 2 sektor yaitu Pertanian, kehutanan dan perikanan; dan Jasa lainnya yang sebelumnya menjadi sektor yang menghambat pertumbuhan.

\section{Analisis Tipologi Klassen}

Setelah mendapat hasil perhitungan dengan membandingkan antara daerah yang diteliti (Kabupaten Cilacap dan Kabupaten Sukoharjo) dengan daerah acuan Jawa Tengah, berikut ini adalah perincian dari Analisis Tipologi Daerah:

\begin{tabular}{l} 
Gambar 4.4 Posisi Tipologi Daeraah Kabupaten Cilacap dan Kabupaten \\
Sukoharjo. \\
\begin{tabular}{|c|c|}
\hline $\begin{array}{c}\text { Kuadran I } \\
\text { Daerah cepat maju dan cepat } \\
\text { berkembang: } \\
\text { Kabupaten Sukoharjo }\end{array}$ & $\begin{array}{c}\text { Kuadran III } \\
\text { Daerah berkembang cepat }\end{array}$ \\
\hline Kuadran II & Kuadran IV \\
Daerah maju tapi tertekan & $\begin{array}{c}\text { Daerah realitif tertinggal: } \\
\text { Kabupaten Cilacap }\end{array}$ \\
\hline
\end{tabular} \\
\hline
\end{tabular}

Berdasarkan gambar diatas, dapat dijelaskan bahwa Kabupaten Cilacap diklasifikasikan menjadi Kudran IV, karena memenuhi kriteria yang ada untuk daerah relatif tertinggal dan Kabupaten Sukoharjo di klasifikasikan menjadi Kuadran I, karena memenuhi kriteria yang ada untuk menjadi daerah cepat maju dan cepat berkembang. Berikut ini penjelasan klasifikasi Kabupaten Cilacap dan Kabupaten Sukoharjo berdasarkan kuadran masing-masing:

1. Kuadran I (yi>y, ri>r): Kuadran I yaitu daerah cepat maju dan cepat tumbuh (high growth and high income) merupakan laju pertumbuhan PDRB dan pendapatan perkapita lebih tinggi dari rata-rata pertumbuhan dan pendapatan perkapita rata-rata nasional.

2. Kuadran IV $(y i<y, r i<r)$ : yaitu daerah relatif tertinggal (low growth and low income) adalah daerah yang masih mempunyai tingkat pertumbuhan dan pendapatan perkapita lebih rendah dariapda ratarata nasional.

\section{SIMPULAN}

1. Berdasarkan hipotesis pertama yang menyatakan adanya sektor basis dan sektor non basis di 2 Kabupaten di Jawa Tengah berdasarkan tabel dibawah dijelaskan:

Tabel 4.23: Perbandingan Sektor Unggul di 2 Kabupaten

\begin{tabular}{|l|c|c|}
\hline & Kabupaten Cilacap & Kabupaten Sukoharjo \\
\hline LQ & 7 & 10 \\
\hline Shift Share(PR) & 16 & 16 \\
\hline Shift Share(PS) & 10 & 10 \\
\hline Shift Share(DS) & 10 & 9 \\
\hline Total & 43 & 45 \\
\hline
\end{tabular}

Sumberi Lampiran - Diolah

Kabupaten Cilacap memiliki tujuh sektor basis yaitu sektor pertanian, kehutanan, dan perikanan; pertambangan dan penggalian; pengadaan listrik dan gas; pengadaan air, pengelolaan sampah, limbah dan daur ulang; konstruksi; transportasi dan pergudangan; serta real estate. Sepuluh sektor lainnya termasuk dalam sektor non basis. Diketahui bahwa sektor basis dengan rata-rata tertinggi ada pada sektor pertambangan. Meskipun kontribusinya terhadap PDRB tidak terlalu besar tetapi sektor ini masuk dalam sektor basis dengan nilai $>1$ yaitu 2,50 melihat sumber daya alam yang ada di Kabupaten Cilacap sehingga sektor pertambangan dan penggalian dinilai memiliki keunggulan kompetitif di daerah Kabupaten Cilacap. Sektor Industri pengolahan merupakan sektor non basis di Kabupaten Cilacap tetapi juga merupakan sektor yang memberikan kontribusi terhadap PDRB meskipun bukan termasuk sektor basis namun sektor tersebut memiliki potensi yang tinggi untuk dikembangkan, dengan melihat kawasan perindustrian yang ada di Kabupaten Cilacap.

Sedangkan Kabupaten Sukoharjo Memiliki Sepuluh Sektor Basis antara Lain Industri Pengolahan; Pengadaan Listrik dan Gas; Perdagangan Besar dan Eceran, Reparasi Mobil 
Dan Sepeda Motor; Transportasi dan Pergudangan; Akomodasi dan Makan Minum; Informasi dan Komunikasi; Jasa Keuangan dan Asuransi; Real Estate; Jasa Perusahaan; serta Jasa Kesehatan dan Kegiatan Sosial. Sektor-sektor yang termasuk dalam sektor basis tersebut merupakan sektor yang mampu memenuhi kebutuhan di dalam Kabupaten Cilacap dan Kabupaten Sukoharjo bahkan juga mampu untuk memasok kebutuhan yang ada diluar daerahnya. Sedangkan sektor-sektor yang termasuk dalam sektor non basis merupakan sektor yang hanya mampu memenuhi kebutuhan masyarakatnya dan belum mampu untuk memenuhi permintaan dari luas daerahnnya.

2. Menurut hipotesis kedua yang menyatakan terdapat perbedaan pengaruh investasi (PMDN) terhadap pertumbuhan sektor basis dan sektor non basis. Menurut nilai koefisien dinyatakan bahwa investasi berpengaruh positif terhadap PDRB sektor basis di Kabupaten Cilacap dan Kabupaten Sukoharjo. Berdasarkan uji parsial Investasi secara parsial berpengaruh positif dan signifikan terhadap PDRB sektor basis di Kabupaten Cilacap dan Kabupaten Sukoharjo. Namun Investasi secara parsial berpengaruh negatif dan signifikan terhadap PDRB Sektor non Basis kabupaten Cilacap serta Investasi secara parsial tidak berpengaruh signifikan terhadap PDRB Sektor non Basis Kab. Sukoharjo. Tetapi dalam uji simultan secara bersama-sama variabel Investasi berpengaruh secara signifikan dan berarah positif terhadap PDRB Sektor basis dan PDRB sektor non basis di Kabupaten Cilacap dan Kabupaten Sukoharjo. Jika investasi meningkat maka PDRB sektor non basis akan mengalami penurunan. Oleh karena itu dapat disimpullkan bahwa sektor non basis dapat mengimbangi sektor basis dalam daerahnya. Jika Investasi meningkat maka PDRB sektor basis pun akan meningkat.

3. Menurut hipotesis ketiga adanya pertumbuhan sektor ekonomi di Kabupaten Cilacap dan Kabupaten Sukoharjo. Berdasarkan tabel diatas, dapat dilihat bahwa di Kabupaten Cilacap terdapat 7 sektor Basis, 16 sektor yang dapat mendorong pertumbuhan PDRB Jawa Tengah, 10 sektor yang tumbuh relatif cepat di Provinsi Jawa Tengah, dan 10 sektor yang memiliki keuntungan lokasional. Sedangkan Kabupaten Sukoharjo memiliki 10 sektor Basis, 16 sektor yang mendorong pertumbuhan PDRB Jawa Tengah, 10 sektor yang tumbuh relatif cepat di Provinsi Jawa Tengah, dan 9 sektor yang memiliki keuntungan lokasional. Sehingga dapat disimpulkan bahwa Kabupaten Sukoharjo adalah kabupaten yang lebih unggul dari pada Kabupaten Cilacap dilihat dari jumlah sektor unggulannya.

4. Menurut hipotesis keempat berdasarkan analisis Tipologi Klassen, dapat dijelaskan bahwa Kabupaten Cilacap diklasifikasikan menjadi Kudran
IV, karena memenuhi kriteria $(\mathrm{yi}<\mathrm{y}, \mathrm{ri}<\mathrm{r})$ yang ada untuk daerah relatif tertinggal dan Kabupaten Sukoharjo di klasifikasikan menjadi Kuadran I, karena memenuhi kriteria (yi $>y$, ri $>$ r) yang ada untuk menjadi daerah cepat maju dan cepat berkembang.

\section{Saran}

1. Adanya pengembangan sektor-sektor basis diharapkan dapat menjadi arus pendapatan dari luar daerah Kabupaten Cilacap dan Kabupaten Sukoharjo. Sehingga dapat meningkatkan pendapatan daerah melalui sektor sektor ekonomi yang bersangkutan. Peningkatan pendapatanqini diharapkan juga dapat meningkatkan konsumsi dan investasi bagi sektorsektorqyang bersangkutan dan dapat menunjang permintaan pada sektor sektor ekonomi yang merupakan sektor non basis.

2. Berdasarkan hasil penelitian diketahui bahwa Investasi dalam penelitian ini Penanaman modal dalam negeri mempunyai pengaruh terhadap PDRB sektor basis dan sektor non basis. Oleh karena itudiharapakan pemerintah daerah dapat mengarahkan kebijaksanaannya membangun sarana dan prasarana yang ada dan dapat memanfaatkan setiap potensi-potensi yang ada di Kabupaten Cilacap dan Kabupaten Sukoharjo. Dengan begitu diharapkan dapat menarik investorinvestor untuk menanamkan modalnya. Sehingga apabila banyak investor masuk maka dapat menambah penyerapan tenaga kerja dan faktor-faktor kemiskinan menurun sehingga dapat membantu pertumbuhan ekonomi di Kabupaten.

3. Untuk peneliti selanjutnya diharapkan dapat menambah variabel-variabel lain diluar variabel dalam penelitian ini dengan harapan akan mem permudah dalam identifikasi dan pelaksanaan strategi pembangunan daerah.

\section{DAFTAR PUSTAKA}

Arsyad, L. (2004) Ekonomi Pembangunan; Edisi Keempat. 4th edn. Yogyakarta: Sekolah Tinggi Ilmu Ekonomi YKPN.

Badan Pusat Statistik (2020) Jawa Tengah Dalam Angka 2020. Available at: jateng.bps.go.id.

Devi, N. M. W. S. and Yasa, I. N. M. (2018) 'Analisis Sektor Potensial Dalam Menetapkan Perencanaan Pembangunan Di Kabupaten Karangsem', EJurnal EP Unud, 7(1), pp. 152-183.

Purnamasari, C. R. (2015) Analisis Faktor-Faktor yang Mempengaruhi Penanaman Modal Dalam Negeri Di Indonesia Tahun 1994-2014. Available at: https://repository.usd.ac.id/2930/2/111324014_ful l.pdf.

Siwi, C. P. (2018) 'Analisis Pengaruh Investasi, Tenaga Kerja dan Tingkat Suku Bunga Terhadap 
Margaretha Dwi Suprapti Setyaningrum, Niniek Imaningsih dan Riko Setya Wijaya, Analisis Sektor Ekonomi Serta Pengaruh Investasi terhadap Sektor Basis Dan Non Basis 2 Kabupaten Di Provinsi Jawa Tengah

Pertumbuhan Ekonomi di Indonesia Tahun 19902015 .

Sjafrizal (2012) Ekonomi Wilayah dan Perkotaan. Jakarta: PT. Rajagrafindo Persada.

Sukirno, S. (2004) Pengantar Teori Makroekonomi. Jakarta: PT Raja Grafindo Persada.

Sugiyono (2017) Metode Penelitian Kuantitatif, Kualitatif, dan $R \& D$. Bandung: Alfabeta, CV. 